\title{
Comparison of psychological factors' control effect model in the relationship between athletes' retirement factors and athletes' vitality
}

\author{
Jin-Seok Chae* \\ Seoul National University of Science and Technology
}

\begin{abstract}
[Purpose] The purpose of this study was to compare the differences between the three simple control models of Hayes (2012) and to determine whether there were Moderating Effects depending on the level of self-esteem, willpower and belief that are psychological factors in the relationship between athlete's retirement and Athlete's period. [Methods] To achieve this objective, a total of 259 retirees were collected from data on retirement and psychological factors. The data processing method presented the reliability and feasibility of the measuring instrument through technical statistics, frequency analysis, confirmation factor analysis, and reliability analysis. In addition, we conducted a hierarchical regression analysis using the PROCESS command statement in IBM 20 to examine the regulatory effects. [Results] The results of the study are as follows: The first was the significant model of Hayes (2012)'s three simple control models. It is up to the researcher to choose which model to choose, but when selecting the model, the justification of the variables must be established on the basis of theoretical basis, and the reliability of the variables must be put in to produce reliable and reasonable results. The second was to verify that the relationship between the retirement factor(10) and the Athlete's period has an adjustment effect based on self-esteem, willpower and belief. Among the psychological factors, the Moderating Effects was greatest in the influence of belief on the Athletes' period, and the more reasons for retirement, the longer the Athletes' period than the weaker. The combined mental strength of all three psychological factors combined shows that the combined effect of control also significantly increases the player's ability to survive by combining with the retirement factor. In particular, sportsmanship has resulted in a better mix of retirement factors than the sense of Self-esteem and will, resulting in a longer increase in the capacity. [Conclusion] Therefore, players who long for a player always keep their dreams of becoming a big star in mind, and ask me to always keep the belief in hope that I will enjoy my career for a long time.
\end{abstract}

Key words: Moderating Effects, Retirement factors, psychological factors

\section{서 론}

논문 투고일 : 2019. 03. 07.

논문 수정일 : 2019. 11. 12.

게재 확정일 : 2020. 01. 02.

* 교신저자 : 채진석(chejinseok@ hanmail.net).

* 이 논문은 2014년 한국연구재단 인문사회학술연구교수 지원 사업에 의하여 수행된 연구임(2014S1A5B5A02016834).
은퇴요인이 발생하면 선수는 어떤 자세를 취할까? 한 예로 프로진출에 실패하고 은퇴하여 진로전환 과정을 경 험한 대학야구선수 7명을 대상으로 심층 면담한 결과 진 로불안과 진로전환 고민이 처음 시작 이였다고 한다 (Park, et al., 2016). 진로 전환 준비와 과정을 거치면 
서 진로결정과 새로운 비전, 아쉬움과 자기만족으로 도출 되었다는 이 연구는 현역선수의 은퇴원인에 따른 진로상 담이 필요함을 보여준다. 이처럼 운동선수는 여러 상황에 서 은퇴원인이 발생하면 고민과 함께 은퇴를 미룰 것인가 아니면 다른 길을 찾을 것인가의 갈등 속에서 심리적 부 담감을 앉고 이 은퇴문제를 대할 것이다(Lerch, S. H., 1984). 은퇴시기의 결정은 은퇴원인의 정도에 차이와 심 리요인에 의해 결정될 것이다.

운동선수가 경기력이 좋은 선수라도 프로선수로의 평 균기간이 3내지 4년간이라 했고, 프로선수생활은 길어야 30 대 전, 후반이며, 부상을 당하거나 후보로 떨어지는 시 기가 은퇴를 고려 할 시기라고 언급했다(Eitzen \& Sage, 1997). 종목에 따라 다르겠지만 30살이 되면 은퇴 를 떠올리며, 한국의 국가대표선수는 20 에서 30 대에 은 퇴를 한다고 하였다(Lee, 2008). 은퇴하지 않고 현역을 연장시킬 수 있는 비결은 무엇일까? 은퇴원인을 제거하 면 될 것이다. 그러나 불가항력적인 은퇴원인도 있을 수 있고 그렇지 않을 수도 있다. 선수에게 은퇴원인이 발생 한다면 개인에 따라 정도의 차이는 있겠지만 심리적 저항 은 존재한다(Coakley, 1983; McKenna \& Thomas, 2007).

선수마다 은퇴에 대처하는 형태가 다를 것이고 받아드 리는 자세 또한 다를 것이다. 심리적 자존감의 크기와 의 지와 믿음의 수준에 따라 선수생명력 (20살 이상 은퇴까 지 선수 생활 기간)에 차이가 일을 것이라는 연구는 아직 찾지 못했다. 그러나 심리요인이 조절변수가 되어 종속변 수에 영향을 주는 논문은 다수 존재 한다(Yoon et al., 2011; Kwak, 2012; Park \& Kim, 2013; Park \& Yoo, 2014; 2014; Kim et al, 2015; Kim \& Cho, 2016; Baek \& Yang, 2016; Kim, 2017; Choi, 2018). 은퇴 원인이 각각의 선수에게 다르듯이 개인의 심리적 요인의 수준도 다름에 따라 선수 생활 유지 기간인 선수생명력에 차이가 있음을 밝힌다면 은퇴시기를 늦추고 싶은 선수에 게는 좋은 상담 자료이다.

최근 2016년 이후 4년간 스포츠분야의 조절효과 (Moderating Effects)와 관련된 논문은 약 115 편이였고 이 중 심리요인이 조절변수로 제시되어 검증하려는 논문 들이 스포츠 분야에서 꾸준히 증가하고 있다. 이 조절효 과는 경기력향상에 관심을 두고 있는 스포츠과학자들에
게 다양한 스포츠분야에서 일어나는 현상에 대한 이해를 증진시킬 수 있다는 점에서 그 의미가 크다. 특히, 변인들 간에 존재하는 복잡한 관계를 이해할 수 있을 뿐 아니라 현장에서 경기력과 관련하여 시너지효과의 원인을 찾을 수 있는 아이디어이다.

조절변수는 독립변수와 종속변수의 관계 방향 또는 강 도에 영향을 미치는 변수라 한다(Baron \& Kenny, 1986). 이 조절변수는 종속변수에 영향을 주는 제 2 의 독 립변수로 둘 사이관계는 조절변수 수준(level)에 따라 달 라지는데 이러한 이유 때문에 독립변인이 조절변인과 상 호작용해서 종속변인(criterion variable)에 영향을 미친 다고 한다(Seo, 2010). 따라서 조절효과(Moderating Effects)와 관련된 조절변수 선정은 관련 이론을 근거를 기초로 해야 한다(Baron \& Kenny.,1986; Jaccard et al., 1990). 이를 토대로 은퇴요인이 선수생활 기간에 영 향을 줌에 있어서 심리요인인 자존감, 의지, 믿음이 의미 있게 조절 할 것이다. 본 연구의 조절변수로 자아존중감 (self-esteem)은 자신이 사랑받을 만한 가치가 있는 소중 한 존재이고 어떤 성과를 이루어낼 만한 유능한 사람이라 고 믿는 마음이다. 자아존중감은 학업 성적, 리더십, 위기 극복능력, 대인관계 등 삶의 많은 영역에 영향을 미친다. $\operatorname{Kim}(2017)$ 은 자원의 속성을 기반으로 한 빈곤가정의 탄 력성 형성에 영향을 미치는 요인들로 교육수준과 믿음, 사 고, 자아존중감등 심리적 요인을 들었다. Jeon(2014)은 대학선수의 중도 탈락 시 심리적 불안감을 제시하였다. Yoon et al., (2011)은 저소득가정의 아동 - 청소년의 스 포츠바우처 참가와 셀프리더십 간에 자아존중감 및 자아 효능감의 매개 및 조절효과를 검증하였고 Choi(2018)은 유소년 운동참여자들의 자기효능감, 자아존중감 및 학교 생활적응의 구조적 관계에서 전문성수준을 조절변수로 하여 중재효과를 제시하였다.

의지력(意志力)이란 어떤 일에 무엇인가를 하려는 마 음의 작용으로 이루고자 하는 마음을 꼿꼿하게 지켜 나가 는 힘이다. 좁은 뜻으로는 두 개 이상의 하고 싶은 일이 있어서 그 어느 하나를 선택하여 그것을 하고자 결심하는 것을 말한다. 즉, 은퇴원인이 발생하여 은퇴의 기로에 섰 을 때 은퇴 할 것인지 아니면 좀 더 지켜나아 갈 것인지는 선수의 의지력에 달려있다. Sin \& Kang(2014)은 의지 력과 집중력은 경기력에 영향을 미치는 요인으로 나타났 
다. Lee \& $\operatorname{Kim}(2009)$ 은 심리기술이 자기관리에 미치는 영향력에서 의지력은 대인관리와 훈련관리에 영향을 미 치는 것으로 나타났다고 하였다. 또한 $\mathrm{Kim} \&$ $\operatorname{Kim}(2010)$ 은 태권도선수의 경기력 심리결정 요인의 중 요도 산출에서 의지력의 중요성을 제시하였고 스포츠 재 능의 개인적 특성은 신체능력(동적체력, 정적체력, 체격)과 정신능력(집중력, 의지력, 조절력)의 차원으로 나타났다.

믿음은 본 연구에서는 능력믿음을 말한다. 능력믿음은 Dweck(1986)이 학습영역에서 목표의 개념화를 설명하 기 위해 처음으로 제안한 능력의 자기이론(self-theories of ability)에서 시작한다. 이를 기초로 Heyman \& Dweck(1992)은 운동선수의 믿음이 자신의 목표성향, 자기조절, 노력, 내적동기 등 인지적, 정서적 그리고 행동 적 결과에 영향을 준다고 하였다. 스포츠 상황에서도 Sarrazin et al(1996)은 성취목표와 능력믿음과의 관계 를 알아본 결과, 자기성향의 학생 보다 과제성향의 학생 들의 운동능력이 더 향상 되었다고 하였다.

$\operatorname{Kwak}$ (2012)은 여자체조선수들의 성취목표성향이 스 포츠능력믿음과 체조효능감에 미치는 영향력은 자기관 리에 의해 어떻게 조절되는지를 규명하였다. Park \& $\operatorname{Kim}(2013)$ 은 학생 운동선수의 스포츠능력믿음과 성취 목표 및 행동조절의 구조적 관계에서 스포츠 능력믿음과 성취목표 및 행동조절간의 구조적 관계를 검증한 결과, 학습과 노력에 의해 증가된다고 보는 믿음은 과제성향목 표를 예측하고 과제성향목표는 지각된 유능감의 매개를 통해서 뿐만 아니라 직접 행동조절에 영향을 미친다고 하 였다. 이는 본 가설의 믿음이 행동영역에 영향을 줄 것이 라는 점과 일치한다.

정신력을 본 논문에서는 자아존중감 + 의지 + 믿음으로 정의 하였다. 정신력 $($ 자존감 + 의지 + 믿음)이 은퇴요인과 어우러져 선수생명력에 조절효과를 보이고 있는지 알아보 았다. 그 결과 정신력이라는 조절변수는 은퇴요인이 선수 생명력에 미치는 영향에서 은퇴요인과 어우러져 유의미한 조절효과를 나타내고 있었다. 현대 심리학 연구가 진행된 현재에는 정신력이라는 조작적 정의가 어려운 개념보다는 “동기 이론"(motivation), “회복탄력성”(resilience), “심 리적 강인성"(mental toughness/hardiness)에 가까운 개념으로 이해되고 있다(Kwon et al, 2018). 정신력과 관련된 선행연구에서 Kim et all(2010)은 태권도 선수
들의 정신력 개념 구조 파악에서 정신력 개념은 집중력, 자신감, 투혼, 승부욕, 최선의 노력 등으로 정리하고 Kim et al(2017)은 스포츠자신감의 모든 하위요인과 정 신력의 불굴의 투지간의 관계에서 과제성향은 부분매개 효과가 나타났다고 하였다.

현재 은퇴준비 기간 동안 나타나는 심리적 요인을 다 루는 논문은 그리 많지 않다(Jang, 2016; Won \& Kim, 2017; Won et al., 2018). 특히 은퇴원인을 밝히고 은퇴 당시 심리요인을 측정하는 측정도구개발은 더욱 그렇다 (Kim et al., 2015; Won \& Kim, 2017; Chae et al., 2018). 중도포기의 사유는 여러 문제점이 있겠지만, Oldridge(1984)의 운동참가에 관한 연구에서 운동에 대 한 참여의 지속성을 향상시키거나 감소시키는 요인은 연 령, 직업형태, 생활양식 등이 개인에 영향을 미치고 그들 이 선수로써 지속적으로 참여하거나 중도포기하게 되는 결과를 가져온다고 하였다.

은퇴원인이 현역선수 기간에 영향을 줄 것이라는 논문 은 쉽게 찾아 볼 수 있다. Park et al(2018)은 운동선수 의 은퇴요인의 주요인자는 부상이며, 부상을 당하면 부상 기간 동안 운동 감각 또한 떨어지게 되어 경기 출전이 줄 어들며, 더구나 부상기간이 길어지면 성적도 하락하여 은 퇴시기가 당겨진다고 하였다. 그리고 축구 국가대표 팀으 로 있었던 모 선수는 30살이라는 젊은 나이에 부상으로 은퇴를 하게 되었다고 한다. 운동선수는 실업이나 프로팀 에서 선수생활 도중 부상과 체력 및 성적저하, 진로변경, 계약해지 등 여러 요인으로 은퇴하는 경우가 대부분이다. 은퇴에 따른 고민의 정도는 차이가 있겠지만 선수 개개인 에 다가오는 심리적 요인의 충격의 크기는 다를 것이다 (Chae et al., 2018). 이러한 선행연구관점에서 선수들 에게 은퇴요인이 발생 했을 때 심리적 요인 중 자존감, 의 지, 믿음은 선수생명력에 어떤 영향력을 발휘 할 것인지, 즉 심리적요인이 은퇴요인과 어우러져 선수생명력에 유 의미한 시너지효과가 일어날 것인지 예측한다.

따라서 본 연구는 Hayes(2012)의 단순조절모형 3가 지를 이용하여 위계적조절회귀모형의 차이를 서로 비교 함과 동시에 이를 토대로 운동선수의 은퇴요인과 선수생 명력간의 관계에서 심리요인인 자존감, 의지력, 믿음의 수준에 따라 영향에 차이가 있는지 밝히고자 하는 것이 목적이다. 이러한 연구의 궁극적인 목적은 현재 은퇴를 
고민하는 현역선수들에게 은퇴원인이 발생 시 고민으로 불안에 떠는 것보다는 심리적 요인을 강화한다면 주도적 으로 선수생명력을 조절할 수 있다는 이론적 근거를 마련 하고자 함이다.

\section{연구문제와 가설}

문제1. Hayes(2012)의 단순조절모형 3가지 비교는 어떤 의미인가?

문제 2. 은퇴요인과 선수생명력에 관한 심리요인의 조 절효과

가설1. 자존감에 따라 은퇴요인이 선수생명력에 미치 는 영향력에 차이가 있을 것이다.

가설2. 의지에 따라 은퇴요인이 선수생명력에 미치는 영향력에 차이가 있을 것이다.

가설3. 믿음에 따라 은퇴요인이 선수생명력에 미치는 영향력에 차이가 있을 것이다.

가설4. 정신력에 따라 은퇴요인이 선수생명력에 미치 는 영향력에 차이가 있을 것이다.

\section{연구방법}

\section{연구대상 및 자료수집}

연구대상은 대한체육회에 3년 이상 선수등록을 필한 자로서 대학선수 이후 은퇴한 자를 대상으로 모집단을 형 성하였다. 은퇴요인이란 더 이상 선수로서 대한체육회에 등록을 할 수 없는 상황에 이르게 한 요인을 말한다. 본 연구를 위한 측정도구는 Chae et al(2018)가 개발한 설 문지를 이용 하였다. 2017년까지 전국에 거주하고 있는 은퇴자를 대상으로 비확률표집인 편의 표집을 실시하였 다. 1 차, 2 차 설문조사한 결과 중 답변이 불성실하거나 결측값이 많은 자료는 제외하고 259 명의 설문자료를 사 용하였다. 피험자의 특성은 〈Table 2>에 제시하였다.

이 은퇴요인 척도는 Chae et al(2018)개발한 측정도 구를 이용하여 71문항 (5점척도-전혀아니다. 아니다. 보 통이다. 그렇다 아주그렇다)이 사용되었다. 설문조사한 자료를 기초로 하여 은퇴원인 13 개변인 중에서 탐색적요
인분석을 통해 잠재변인 10 가지 (54문항)인 사고중독, 직 업계획, 가족경제, 인기, 단체생활, 부상, 대인관계, 경쟁 력, 운동자세, 계약으로 축소 할 수 있었다(Table 1).

은퇴심리적변인에 사용된 척도는 자존감, 의지, 믿음 이며, 자존감은 Rogenberg가 1965년에 개발한 자존감 척도와 Choi(2018)가 사용한 자아존중감 척도를 의지는 $\mathrm{Yoo}$ (2011)의 다차원적 스포츠 재능발달 척도의 개발의 위계성과 동일성 분석에서 제시한 의지력 문항을 믿음은 박중길, 김기형 (2010)이 개발한 스포츠 능력믿음과 행 동 조절을 측정 검사지를 이용한 문항을 본 연구 목적에 맞 게 수정 보완하여 전문가 1 차, 2 차 회의를 거쳐 재구성하 였다. 이렇게 하여 총 15 개 문항 중 탐색적요인분석을 통 해 12 개 문항에 잠재변인 3 가지(자존감, 의지, 믿음)로 구성 하였다(Table 1).

Table 1. Variables and Items

\begin{tabular}{|c|c|c|c|}
\hline Variable & Independent variable & Control variable & $\begin{array}{c}\text { Dependent } \\
\text { variable }\end{array}$ \\
\hline Items & $\begin{array}{l}\text { 1.Accident(9) } \\
\text { 2.Jobplan(7) } \\
\text { 3.Popularity(3) } \\
\text { 4.Economy(10) } \\
\text { 5.Relationship(5) } \\
\text { 6.Injury(3) } \\
\text { 7.Competitiveness(6)8. } \\
\text { Posture (4) } \\
\text { 9.Group(3) } \\
\text { 10.Contract(4) }\end{array}$ & $\begin{array}{l}\text { 1.Self-esteem(4) } \\
\text { 2.Willingness(4) } \\
\text { 3.Belief(4) }\end{array}$ & $\begin{array}{l}\text { 1.Athletes' } \\
\text { Period(1) }\end{array}$ \\
\hline
\end{tabular}

\section{측정도구의 타당도와 신뢰도}

본 연구의 목적에 부합하는 측정도구의 타당도와 신뢰 도는 확인적요인분석과 크롬바하 $\alpha$ 을 실시하여 제시하 였다. 설문지 문항의 내용타당도는 전문가 집단(교수 12 인)으로 검증하였다. 수렴타당도와 판별타당도의 검증을 위해 확인적요인분석을 실시하였다. 은퇴요인에서의 개 념신뢰도(composite reliability:CR)는 .775-.956, 분 산추출지수(AVE)는 .537-.879까지 나타났고(Table 3) 심리적요인에서의 개념신뢰도 $(\mathrm{CR})$ 는 .875-.924, 분산 추출지수(Average Variance Extracted: AVE)는 .644 .752까지 나타났다(Table 3). 
Table 2. subject's characteristics

\begin{tabular}{ccrl}
\hline \hline Item & Level & $\mathrm{N}$ & $\%$ \\
\hline \multirow{3}{*}{ Gender } & Female & 62 & 23.9 \\
& Male & 197 & 76.1 \\
\hline \multirow{3}{*}{ Age at Retirement } & in one's early twenties & 138 & 53.3 \\
& in one's late twenties & 76 & 29.3 \\
& in one's thirties or older & 45 & 17.4 \\
\hline Characteristics of & speculative stocks & 128 & 49.4 \\
events & a non-speculative sport & 131 & 50.6 \\
\hline By the number of & Personal event & 169 & 65.3 \\
athletes & Group event & 90 & 34.7 \\
\hline Injury experience & Have & 218 & 84.2 \\
status & None & 41 & 15.8 \\
\hline Operation & Have & 110 & 42.5 \\
experience status & None & 149 & 57.5 \\
\hline & University teams & 121 & 46.7 \\
Affiliation & Business sport teams & 97 & 37.5 \\
& Professional teams & 41 & 15.8 \\
\hline \multirow{2}{*}{ The monthly } & 2 million won lower & 106 & 40.9 \\
income of one's & Over 2 million won and & 67 & 25.9 \\
career & under 5 million won. & & \\
& 5 million won in excess & 86 & 33.2 \\
\hline \hline
\end{tabular}

Fornell \& Lacker(1981)가 제시한 .70과 .50보다 모 두 높았다. 따라서 수렴타당도는 검증되었다. 또한 은퇴 요인의 분산추출지수의 최소값인 .537과 심리요인의 분 산추출지수의 최소값인 .644가 상관계수의 제곱값 중 가 장 큰 값보다 크게 나타나 본 자료는 판별타당도가 성립 한다. 즉, 잠재변인 간 상관성이 판이하다는 결과이다.

확인적요인분석의 은퇴요인 적합도를 살펴보면 $\mathrm{Q}\left(2.19, P\left(.05, \quad, \chi^{2}=1200.6, d f=549\right)\right.$ 값이 영가 설을 기각하는데 이는 표본의 크기가 상당히 큰 경우로 이때 다른 적합도인 $T L I=.931, C F I=.943$, $\mathrm{RMSEA}=.060$ 를 본다. 심리적요인 또한 $\mathrm{Q}(2.95)$ 값이 자료와 모형이 부합하지 않으나, $\chi^{2}=380.5, d f$ $=129, \quad(P .05)$, 다른 적합도인 $T L I=.942$, $C F I=.953, \quad \mathrm{RMSEA}=.073$ 이 Bentler, \& Bonett(1980)가 제시한 TLI와 CFI값이 .90이상, $\mathrm{RMSEA}$ 는 .08이하이면 어느 정도 모집단의 근사치 오차 를 받아들일 수 있으며, 모형의 적합도는 양호하다고 보 고 하였다. 문항의 내적일관성을 알려주는 Cronbach's $\alpha$ 값은 .795-.944(Table 3)로 나타내고 있어 조사도구의
신뢰도 지표 기준인 .70이상임을 확인하였다(Hair et al., 1998). 이 기준으로 볼 때 측정도구의 신뢰성과 타 당성은 충족된 것으로 확인되었다.

\section{자료 분석 절차}

자료 분석 절차의 첫 번째는 수집된 자료를 SPSS Ver. 20.0 을 사용하여 연구대상자의 일반적 특성을 파악하고 코딩 시 오류가 발생했는지 알아보기 위해 기술통계와 빈 도분석을 실시하였고 변인간의 관련 정도를 알 수 있는 상관분석을 실시하였다. 또한 측정도구인 은퇴원인과 심 리요인의 타당도와 신뢰도를 검증하기 위해 확인적요인 분석과 신뢰도분석을 실시하여 평균분산추출지수와 개 념신뢰도 및 Cronbach's $\alpha$ 를 산출하였다.

두 번째는 Hayes (2012)의 조절모형 중 단순조절모형 3 가지를 서로 비교하기 위해 위계적회귀분석을 실시하였 고 IBM 20의 PROCESS macro을 이용하여 검정하였다. Hayes교수는 조절효과, 매개효과, 조절된 매개효과, 매 개된 조절효과 등을 모두 합쳐 76 개의 모델 즉, '조건부 모델'를 분류하여 process어플리케이션을 제공하고 있 다. 그 중 단순조절회귀모형을 〈Fig 2, 3, 4〉에 제시 하였 다. 모형 1 은 독립변수 하나, 조절변수 하나로 이루어진 회귀방정식이며 (Fig 2), 모형2는 독립변수 하나 조절변 수 수가 2개 이상으로 이루어진 회귀모형이다(Fig 3). 모 형 3 은 독립변수 수가 2 개 이상이고 조절변수가 1 개인 회 귀방정식이다(Fig 4). 이상 3가지 회귀방정식을 서로 비 교하고자 1단계는 통제변수, 2 단계는 독립변수(은퇴요 인) 3단계는 조절변수(심리요인). 4단계는 은퇴요인*심 리요인의 상호작용변수가 투입 되었다.

각 단계마다 $\mathrm{F}$ 변화량이 유의미한지를 살펴보고 상호 작용항이 투입된 마지막 4단계에서 $\mathrm{F}$ 변화량의 유의성으 로 조절효과의 유/무를 최종 판단한다. 세 번째는 위계적 회귀분석 방법을 통해서 조절효과를 알아보았다. 즉, 어떤 요인이 조절효과로 작용하여 독립변인 종속변인에 영향을 미칠 때 더 큰 영향을 주는지를 알아보기 위한 것이다. 심리적 요인(자존감, 의지, 믿음)에 따라 은퇴원인이 선수 생명력에 미치는 영향에 차이가 있는지 알아보기 위해 위 계적조절회귀분석(Hierarchic Moderated Regression Analysis)을 실시하였다. 
Table 3. Reliability Analysis of Psychological Factors

\begin{tabular}{|c|c|c|c|c|c|}
\hline Measurement question & $\begin{array}{c}\text { Standardized } \\
\text { Regression } \\
\text { Weights } \\
\end{array}$ & Variances Estimate & $\mathrm{CR}$ & AVE & Cronbach's $\alpha$ \\
\hline Self-esteem 27 & .839 & .223 & \multirow{4}{*}{0.924} & \multirow{4}{*}{0.752} & \multirow{4}{*}{.897} \\
\hline Self-esteem 28 & .848 & .206 & & & \\
\hline Self-esteem 29 & .841 & .219 & & & \\
\hline Self-esteem 30 & .786 & .258 & & & \\
\hline Self-esteem 26 & .525 & .765 & \multirow{4}{*}{0.875} & \multirow{4}{*}{0.644} & \multirow{4}{*}{.842} \\
\hline Willingness 35 & .845 & .207 & & & \\
\hline Willingness36 & .870 & .187 & & & \\
\hline Willingness 38 & .857 & .211 & & & \\
\hline Belief42 & .771 & .411 & \multirow{4}{*}{0.879} & \multirow{4}{*}{0.648} & \multirow{4}{*}{.909} \\
\hline Belief43 & .903 & .179 & & & \\
\hline Belief44 & .874 & .247 & & & \\
\hline Willingness39 & .692 & .604 & & & \\
\hline Accident 36 & .884 & .176 & \multirow{3}{*}{.956} & \multirow{3}{*}{.879} & \multirow{3}{*}{.944} \\
\hline Accident39 & .944 & .092 & & & \\
\hline Accident 41 & .941 & .084 & & & \\
\hline Economy18 & .754 & .445 & \multirow{3}{*}{.903} & \multirow{3}{*}{.758} & \multirow{3}{*}{.876} \\
\hline Economy5 & .868 & .160 & & & \\
\hline Economy6 & .935 & .098 & & & \\
\hline Popularity1 & .490 & .838 & \multirow{3}{*}{.812} & \multirow{3}{*}{.605} & \multirow{3}{*}{.795} \\
\hline Popularity2 & .869 & .245 & & & \\
\hline Popularity3 & .928 & .130 & & & \\
\hline Group3 & .873 & .180 & \multirow{3}{*}{.933} & \multirow{3}{*}{.822} & \multirow{3}{*}{.915} \\
\hline Group24 & .929 & .105 & & & \\
\hline Group25 & .857 & .226 & & & \\
\hline Injury43 & .692 & .892 & \multirow{3}{*}{.775} & \multirow{3}{*}{.537} & \multirow{3}{*}{.827} \\
\hline Injury44 & .865 & .358 & & & \\
\hline Injury45 & .812 & .375 & & & \\
\hline Contract22 & .873 & .200 & \multirow{3}{*}{.910} & & \\
\hline Contract23 & .850 & .317 & & .770 & .906 \\
\hline Contract24 & .901 & .168 & & & \\
\hline Relationship8 & .890 & .215 & & & \\
\hline Relationship9 & .878 & .239 & .918 & .789 & .914 \\
\hline Relationship10 & .887 & .175 & & & \\
\hline Posture16 & .877 & .309 & & & \\
\hline Posture17 & .866 & .372 & .831 & .622 & .867 \\
\hline Posture20 & .745 & .582 & & & \\
\hline Competitiveness4 & .797 & .390 & & & \\
\hline Competitiveness5 & .829 & .280 & .818 & .601 & .801 \\
\hline Competitiveness8 & .701 & .533 & & & \\
\hline Job27 & .695 & .777 & & & \\
\hline Job31 & .875 & .344 & .784 & .550 & .835 \\
\hline Job32 & .822 & .451 & & & \\
\hline
\end{tabular}


예측변수나 조절변수, 종속변수 모두 연속변수이며 1 단계 투입은 가외변인인 성별을 통제하기위해 성별변인을 더미변수로 변환하여 투입하였다. 2단계는 평균집중화한 독립변수을 투입하고 3단계는 평균집중화한 조절변수, 4 단계는 상호작용항 $\{($ 독립변수평균화*조절변수평균화 $)\}$ 을 투입하였다. 원점수를 평균집중화(Mean Centering) 하는 이유는 원점수 그대로 사용하여 예측변인과 조절변 인의 곱으로 상호작용항을 생성한다면 상호작용변수는 예측변수와 조절변수간의 상관이 클 수밖에 없다. 이를 다중공선성(multicollinearity)문제라 한다(Cohen et al., 2003).

이 문제를 해결하기 위해 독립변수에서 독립변수의 평 균값을 빼주고, 다시 조절변수에서 조절변수 평균값을 빼 주어 이들 간의 곱으로 상호작용항을 산출하였다. 상호작 용효과가 유의미 할 경우 조절효과가 어떻게 나타날지를 〈Fig 5, 6, 7〉에 제시하였다. 〈Fig 5, 6, 7〉에서 독립변수 인 은퇴요인의 집단 구분은 평균에서 1 표준편차 아래는 Lower, 평균에서 1표준편차 위는 High로 정하였고 조절 변수 특정값 구분은 평균에서 1표준편차 아래는 Lower, 평균주위는 Middle, 평균에서 1표준편차 위는 High로 정하였다. 이를 기준으로 독립변수와 조절변수 간의 관계 를 나타내는 단순회귀선들의 기울기를 확인 하였다. 이 때 각 회귀선의 기울기가 유의미한지를 확인할 뿐 아니라 집단의 기울기가 유의미하게 차이가 있는지 알 수 있다 (Seo, 2010).

\section{연구결과}

\section{Hayes의 3 가지 단순조절모형비교}

Hayes (2012)가 제시한 3가지 단순조절모형을 〈Fig $2,3,4>$ 에 제시하였다. Fig 1.은 일반적인 조절효과 모 형이다. 심리요인이 선수생명력에 조절효과가 있는지 위 계적회귀분석을 각 단계별로 실시하였다(Table 4).

〈Fig 2〉는 〈Table 4〉의 모형 1에 해당하며, 1단계에서 는 통제변인인 성별요인만 투입하고 2단계에서는 독립변 수인 은퇴변수 10 개를 합 점수(평균) 내어 하나의 변수로 투입하였다. 3단계에서는 조절변수인 심리요인만 투입했
다. 이 심리요인은 자존감 + 의지 + 믿음을 합 점수(평균) 내어 하나의 변수로 한 것이다. 마지막 4단계는 은퇴요인 과 심리요인의 상호작용항만 투입하였다. 심리요인의 조 절효과는 유의하지 $(p=.789)$ 않았다.

〈Fig 3〉은 〈Table 4〉의 모형 2에 해당하며, 모형 2가 모형 1과 다른 점은 3 단계에서 조절변수로 심리요인 3개 를 각각 모두 투입했다는 것이다. 그 결과, 4단계에서 조 절효과는 유의미하지는 않았다( $p>$.05). 〈Fig 4〉는 〈Table 4〉의 모형 3에 해당하며, 모형 3이 모형 2와 다른 점은 2 단계에서 독립변수인 은퇴요인 10 가지를 모두 사 용했다는 점과 3 단계에서 심리요인 3가지를 다시 합 점 수로 하여 한 가지 심리요인(정신력)으로 투입했다는 점 이다.

그 결과 마지막 4단계에서 은퇴요인과 심리요인의 상 호작용으로 선수생명력에 유의미한 $(p=.014)$ 조절효과 가 나타났다(Table 4). 그러나 PROCESS로의 검정은 독립변인이 하나만 투입되게 되어 있어 모형3과의 비교 는 불가능 하였다. 3 가지 조절모형의 결과를 비교해보면 이론적 근거 없이 여러 독립변수나 조절변수를 합점수 내 어 하나의 변수로 조작한다면 모형 1,2 에서의 2 단계에 서처럼 조절변수로 의미가 없게 되며, 오히려 검증력을 떨어드릴 가능성이 높음을 알 수 있다(Chaplin, 1991; Cohen et al., 2003).

Table 4. Comparison of Model

\begin{tabular}{ccccccc}
\hline \hline \multicolumn{2}{c}{ Model } & $R^{2}$ & $\Delta R^{2}$ & $\Delta F$ & $p$ & PROCESS \\
\hline & 1step & .067 & .067 & 18.6 & .001 & \\
Mode & 2step & .073 & .005 & 1.5 & .225 & \\
11 & 3step & .138 & .065 & 19.2 & .001 & $\mathrm{P}>.05$ \\
& 4step & .138 & .001 & .07 & .789 & \\
\hline & 1step & .067 & .067 & 18.6 & .001 & \\
Mode & 2step & .073 & .005 & 1.5 & .225 & $\mathrm{P}>.05$ \\
12 & 3step & .155 & .082 & 8.2 & .001 & \\
& 4step & .176 & .020 & 2.1 & .105 & \\
\hline & 1step & .067 & .067 & 18.6 & .001 & \\
Mode & 2step & .219 & .151 & 4.78 & .001 & \\
13 & 3step & .232 & .014 & 4.37 & .038 & \\
& 4step & .300 & .068 & 2.29 & .014 & \\
\hline \hline
\end{tabular}




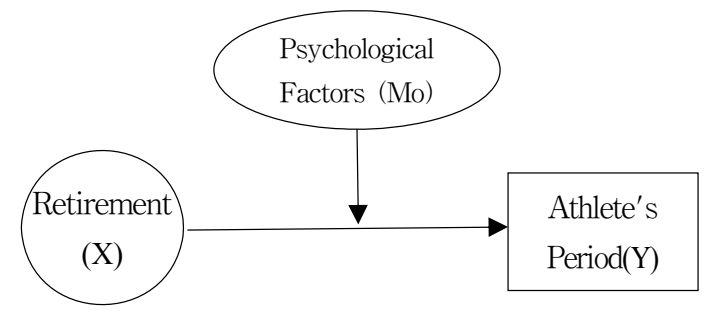

Fig 1. Model of Moderator Effect

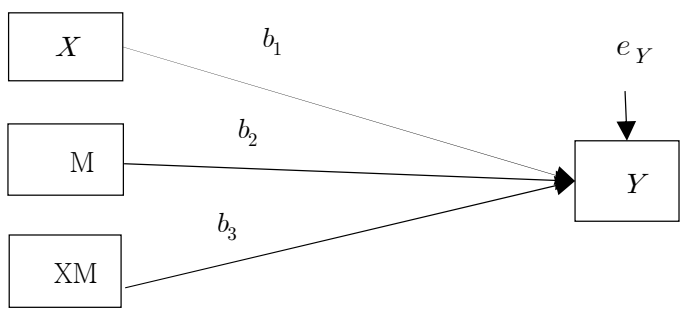

Conditional effect of $X$ on $Y=b_{1}+b_{3} M$

Fig 2. Simple moderated regression model

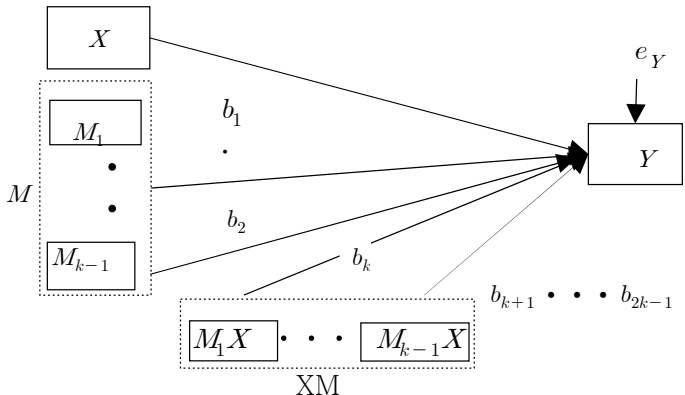

Conditional effect of $X$ on $Y$

$=b_{1}+b_{k+1} M_{1}+\bullet \cdot \cdot+b_{2 k-1} M_{2 k-1}$

Fig 3. Statistical Diagram with multiple modulating variable

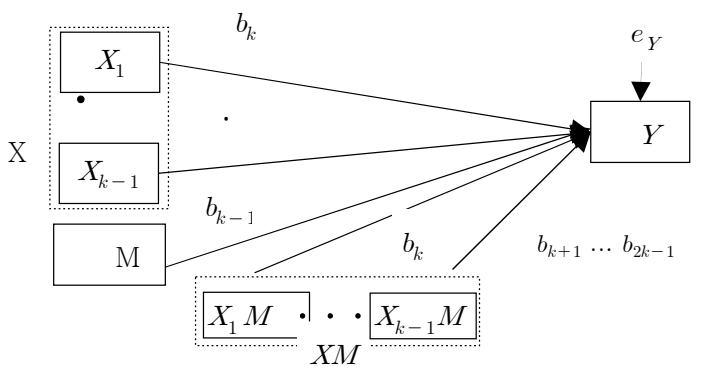

Conditional effect of $X$ on $Y=\left\{\begin{array}{l}b_{1}+b_{k+1} M \\ \dot{\bullet} \\ b_{k-1}+b_{2 k-1} M\end{array}\right.$

Fig 4. Statistical Diagram with multiple Independent variable

\section{2. 심리요인에 의한 조절효과 검정}

자존감에 따라 조절효과가 있는지를 검증하기위해 위 계적조절회귀분석을 실시하였다. 모형 1은 독립변수(은 퇴요인)만을 투입한 회귀모형이다. 모형 2는 독립변수 (은퇴요인) +조절변수를 투입한 모형이다. 모형 3 은 은퇴 요인 +조절변수 + 상호작용변수(은퇴요인"조절변수)모 두를 투입한 회귀모형이다.

〈Table 5〉는 새롭게 투입된 변수들이 $R^{2}$ 과 $F$ 값을 얼 마나 변화시켰는지, 그리고 이러한 변화가 통계적으로 의 미 있는 수준인지를 파악하는 데에 있다. 처음 성별변수 만 투입한 1 단계의 $R^{2}$ 값은 $.067, \mathrm{~F}$ 변화량은 18.593 이 며, 이때 유의하였다( $p<.001)$. 다음 은퇴요인만 투입한 2 단계는 $R^{2}$ 값이 .219 로 모형 1 에 비해 $R^{2}$ 의 증가량은 $.151(15.1 \%)$ 증가 하였고 $\mathrm{F}$ 값의 변화량은 4.778 증가하 여 유의미하였다( $p$ 〈.001). 3단계는 조절변수인 자존감 이 투입되었지만 유의미하지는 못하였다. 그러나 자존감 이 은퇴요인과 어우러진 상호작용항이 투입된 4단계에서

Table 5. Hierarchical Regression Analysis

\begin{tabular}{|c|c|c|c|c|c|}
\hline \multirow{2}{*}{$\begin{array}{c}\text { modulating } \\
\text { variable }\end{array}$} & & \multicolumn{4}{|c|}{ Dependent variable(Athletes' Period) } \\
\hline & & Step 1 & Step 2 & Step 3 & Step 4 \\
\hline \multirow{4}{*}{ Self-esteem } & $R^{2}$ & .067 & .219 & .224 & .302 \\
\hline & $\operatorname{Adj} R^{2}$ & .064 & .184 & .186 & .237 \\
\hline & $\Delta R^{2}$ & .067 & .151 & .005 & .078 \\
\hline & $\Delta F$ & $18.593 * * *$ & $4.778^{* * *}$ & 1.559 & $2.65^{* *}$ \\
\hline \multirow{4}{*}{ Willingness } & $R^{2}$ & .067 & .219 & .230 & .280 \\
\hline & $\operatorname{Adj} R^{2}$ & .064 & .184 & .193 & .213 \\
\hline & $\Delta R^{2}$ & .067 & .151 & .012 & .050 \\
\hline & $\Delta F$ & $18.593 * * *$ & $4.778 * * *$ & 3.786 & 1.640 \\
\hline \multirow{4}{*}{ Belief } & $R^{2}$ & .067 & .219 & .238 & .308 \\
\hline & $\operatorname{Adj} R^{2}$ & .064 & .184 & .201 & .243 \\
\hline & $\Delta R^{2}$ & .067 & .151 & .019 & .070 \\
\hline & $\Delta F$ & $18.593 * * *$ & $4.778 * * *$ & $6.249 *$ & $2.381 *$ \\
\hline \multirow{6}{*}{$\begin{array}{l}\text { Mental } \\
\text { power }\end{array}$} & $R^{2}$ & .067 & .219 & .232 & .300 \\
\hline & $\operatorname{Adj} R^{2}$ & .064 & .184 & .195 & .235 \\
\hline & $\Delta R^{2}$ & .067 & .151 & .014 & .068 \\
\hline & $\Delta F$ & $18.593 * * *$ & $4.778 * * *$ & $4.371^{*}$ & $2.289 *$ \\
\hline & $d f 1$ & 1 & 10 & 1 & 10 \\
\hline & $d f 2$ & 257 & 247 & 246 & 236 \\
\hline
\end{tabular}




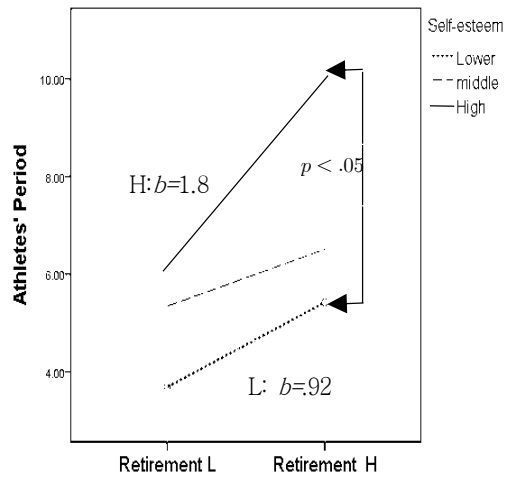

Fig 5. Interaction effect of Self-esteem

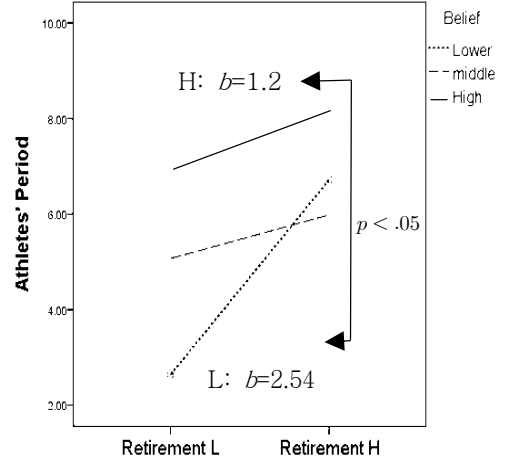

Fig 6. Interaction effect of Belief ability

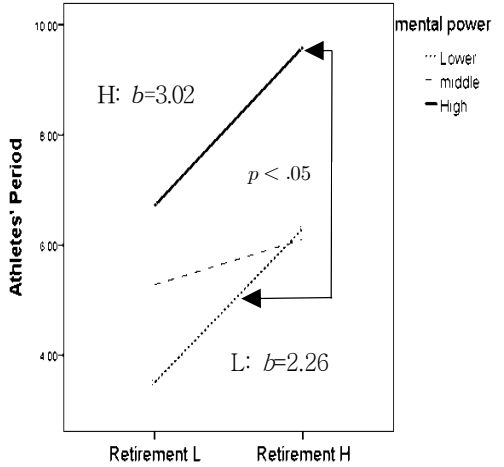

Fig 7. Interaction effect of mental power
는 3 단계보다 $\Delta R^{2}(7.8 \%)$ 을 나타났고 $\mathrm{F}$ 값의 변화량은 2.650 로 증가하여 유의미하였다 $(p<.01)$. 즉, 자존감이 투입된 3단계에서는 유의하지 않았지만 상호작용항(은 퇴요인*자존감)이 투입된 4단계에서는 유의미 하였다.

이것은 자존감이 선수생명력에 조절의 효과를 잘 나타 내고 있는 좋은 사례이다. 조절효과가 유의미한 것을 확 인하였으므로, 조절변수의 어떤 수준에서 어떻게 상호작 용효과가 나타났는지 회귀계수를 이용하여 조절효과에 대한 회귀식을 유도하고 이를 〈Fig 5〉에 제시 하였다. 이 를 살펴보면 자존심이 강한 선수는 약한 선수보다 선수생 명력이 높다는 것이다. 즉, 선수생활이 오래된 경우 은퇴 요인의 인정 폭은 클 것이다. 더불어 이러한 관계 속에서 자존감이 높은 선수는 낮은 선수보다 선수생명력이 크고 지속하는 비율도 더 크게 나타났다.

의지의 수준에 따라 은퇴요인이 선수생명력에 미치는 조절효과가 있었는지 제시하였다. 3단계에서 조절변수 (의지)가 투입되었지만 유의미하지는 못하였다. 최종 상 호작용항이 투입된 4단계에서도 유의미하지 않아 (p>.05) 조절효과가 나타나지 못했다.

믿음이 은퇴요인과 어우러져 선수생명력에 미치는 영 향에서 조절효과가 있었는지 제시하였다. 단계 1 , 단계 2 , 단계 3 , 단계 4 모두에서 유의미하였다. 최종 조절효과의 유의성 판정은 상호작용항이 투입된 마지막 4단계에서 $R^{2}$ 의 변화량(.070)이 유의미하다면 믿음의 수준은 은 퇴요인과 어우러져 선수생명력에 영향을 주고 있다고 할 수 있다.
즉, 믿음이라는 조절변수는 은퇴요인이 선수생명력에 미치는 영향에서 은퇴요인과 어우러져 유의미한 조절효 과를 나타내고 있었다. 조절효과가 유의미한 것을 확인하 였으므로, 조절변수의 어떤 수준에서 어떻게 상호작용효 과가 나타났는지 회귀계수를 이용하여 조절효과에 대한 회귀식을 유도하고 이를 〈Fig 6〉에 제시 하였다. 이를 살 펴보면 은퇴요인이 많을수록 믿음이 강한 선수는 약한 선 수보다 선수생명력은 더 오래 지속되었다. 이러한 관계 속에서 믿음이 약한 선수는 강한 선수보다 선수생명력을 지속하는 변화율이 오히려 컸다.

정신력(자존감 + 의지 + 믿음)이 은퇴요인과 어우러져 선수생명력에 조절효과를 보이고 있는지 알아보았다. 단 계 1 , 단계 2 , 단계 3 , 단계 4 모두에서 유의미하였다. 최종 조절효과의 유의성 판정은 상호작용항이 투입된 마지막 4단계에서 $R^{2}$ 의 변화량(.068)이 유의미하다면 믿음의 수준은 은퇴요인과 어우러져 선수생명력에 영향을 주고 있다고 할 수 있다. 즉, 정신력이라는 조절변수는 은퇴요 인이 선수생명력에 미치는 영향에서 은퇴요인과 어우러 져 유의미한 조절효과를 나타내고 있었다. 조절효과가 유 의미한 것을 확인하였으므로, 조절변수의 어떤 수준에서 어떻게 상호작용효과가 나타났는지 회귀계수를 이용하 여 조절효과에 대한 회귀식을 유도하고 이를 〈Fig 7〉에 제시 하였다. 이를 살펴보면 정신력이 강한 선수는 약한 선수보다 선수생명력에 있어서 더 오래 선수 생활을 지속 되었다.

끝으로 모형3(조절변수: 정신력)을 같은 연구구조로 
구조방정식을 이용한 연구모형과 비교한 결과, 모형 적합 성을 판별 할 수 있는 지수인 $\mathrm{CMIN} / \mathrm{df}(\mathrm{Q})=1.755$ $\left(\chi^{2}: 1231.8, d f: 702, p \nmid .01\right), \mathrm{TLI}=.889$, IFI:.913, $\mathrm{CFI}=.910, \mathrm{RMSEA}=.054$ 가 도출되었다. 이 수치는 수 용기준치인 (RMSEA<.1, or .90<적합도)에 만족할 만한 수준임을 알 수 있었다.

\section{논 의}

본 연구는 Hayes(2012)의 단순조절모형 3가지를 이 용하여 위계적조절회귀모형의 차이를 서로 비교함과 동 시에 이를 토대로 운동선수의 은퇴요인과 선수생명력간 의 관계에서 심리요인인 자존감, 의지력, 믿음의 수준에 따라 영향에 차이가 있는지 밝히고자 하는 것이 목적 이 였다. 이러한 목적을 달성하기 위해 위계적조절회귀분석 을 이용하여 결론을 제시하였다.

첫 번째 결과인 Hayes(2012)의 단순조절모형 3가지 의 비교에서 모형 1 과 모형 2 에서는 조절효과가 나타나지 않았지만 모형3에서 심리요인과 은퇴요인의 상호작용으 로 선수생명력이 길어지는 유의미한 조절효과가 있었다. 모형 1은 독립변수, 조절변수 모두 각각 1개씩 투입하였 다. 즉, 독립변인인 은퇴요인 10 개를 평균 내어 하나의 변수로 만든 것이고 조절변인인 심리요인은 3개를 평균 내어 1 개 변인으로 만든 것이다. 모형 2 또한 독립변수를 10 개에서 1 개로, 조절변수는 3 개에서 3 개로 투입한 것이 다. 모형 3 은 독립변수 10 개에서 10 개로, 조절변수 3 개에 서 1 개로 평균을 낸 것이다. 이처럼 독립변수와 조절변수 를 여러 개를 투입해야 할지 아니면 하나로 해야 할지는 이론적 근거가 마련되어야 한다(Jaccard et al., 1990). 즉, 어떤 모형을 선택하느냐는 연구자의 몫이지만 모형을 선택했을 때는 합리적인 이유가 있어야한다.

모형1과 모형2에서처럼 신뢰도가 높은 독립변수 10개 를 하나의 변수로 변환한다면 신뢰도는 반감 될 것이고 검증력은 떨어드릴 가능성이 높음을 알 수 있다 (Chaplin, 1991; Cohen et al., 2003). 즉, 조절변인과 독립변인의 신뢰도가 낮을 경우 두 변인의 곱으로 만들어 진 상호작용항도 신뢰도가 떨러질 것이다. 그 이유는 상 호작용항은 두 변인의 신뢰도의 곱으로 생성되기 때문이
다(Busemeyer \& Jones, 1983).

상호작용 변수의 신뢰도가 떨어지면 상호작용 표준오 차는 높아지고 결국 상호작용효과에 대한 통계적 검증력 은 내려가게 된다(Aguinis, 1995). 그러나 모형3에서처 럼 의미 있는 독립변수는 모두 살리되 조절변수인 심리요 인인 자존감, 의지, 믿음은 인간의 정신력 안에 상호 공존 하며 비례 관계에 있음이 이론적 배경에 있다면 조절변인 을 사용하는 심리요인 3가지 (자존감, 의지, 믿음)를 하나 의 변수(정신력)로 변환함에 있어서는 의미가 있겠다. 최 종 PROCESS을 이용 Hayes(2012)의 3가지 단순조절 모형을 검정한 결과 모형1과 모형2의 결과는 일치하나 모형3은 비교 불가였다. 왜냐하면 모형3은 독립변인이 여러 개 투입하는 모형 이였으나 PROCESS는 독립변인 을 하나만 투입 할 수 있도록 되어 있었다.

두 번째 연구결과에서 자존감과 은퇴요인이 어우러진 상호작용은 선수생명력에 의미 있는 조절효과를 나타내 었다. 이것은 자존감이 선수생명력에 조절의 효과를 잘 나타내고 있는 좋은 사례이다. 조절효과가 유의미한 것을 확인하였으므로, 조절변수의 어떤 수준에서 어떻게 상호 작용효과가 나타났는지 회귀계수를 이용하여 살펴보면 자존심이 강한 선수는 약한 선수보다 선수생명력이 높다 는 것이다. 즉, 선수생활이 오래된 경우 은퇴요인의 인정 폭은 클 것이다. 더불어 이러한 관계 속에서 자존감이 높 은 선수는 낮은 선수보다 선수생명력이 크고 지속하는 비 율도 더 크게 나타났다.

선행연구에서 자존감과 같은 의미의 자아존중감의 조 절효과에 대해서 연구한 Yoon et al(2011)은 저소득가 정의 아동-청소년의 스포츠바우처 참가와 셀프리더십 간에 자아존중감 및 자아효능감의 매개 및 조절효과가 있 었다고 하였다. 또한 $\operatorname{Kim} \& \mathrm{Cho}(2016)$ 의 연구에서는 자아존중감을 종속변수로 노인의 신체활동 수준을 독립 변수로 성별을 조절변수로 사용하여 노인의 신체활동 수 준이 자아존중감과 사회적지지에 미치는 영향에서 성별 에 따른 조절효과가 있었다고 보고 하였다. Kim et $\mathrm{al}(2014)$ 는 청소년 축구선수들의 자기존중감은 주관적 행복에 긍정적인 영향을 미치는 것으로 보고하였고 선수 들이 지각한 코치의 통제적 행동과 자율성지지 행동은 자 기존중감이 주관적 행복에 미치는 영향을 억제 또는 촉진 시키는 조절효과가 있었다고 보고 하였다. 
다음은 심리요인인 의지의 수준에 따라 은퇴요인이 선 수생명력에 미치는 조절효과가 있었는지 제시하였다. 은 퇴요인이 선수생명력에 영향을 줄 때 자신의 의지수준에 따라 조절효과가 나타나지는 않았다.

믿음이 은퇴요인과 어우러져 선수생명력에 미치는 영 향에서 조절효과가 있었는지 제시하였다. 믿음이라는 조 절변수는 은퇴요인이 선수생명력에 미치는 영향에서 은 퇴요인과 어우러져 유의미한 조절효과를 나타내고 있었 다. 조절효과가 유의미한 것을 확인하였으므로, 조절변 수의 어떤 수준에서 어떻게 상호작용효과가 나타났는지 살펴보면 은퇴요인이 많을수록 믿음이 강한 선수는 약한 선수보다 선수생명력은 더 오래 지속되었다. 이러한 관계 속에서 믿음이 약한 선수는 강한 선수보다 선수생명력을 지속하는 변화율이 오히려 컸다. 믿음은 본 연구에서는 능력믿음을 말한다. 운동선수의 믿음이 자신의 목표성 향, 자기조절, 노력, 내적동기 등 인지적, 정서적 그리고 행동적 결과에 영향을 준다고 하였다(Heyman \& Dweck, 1992). 스포츠 상황에서도 Sarrazin et al. (1996)은 성취목표와 능력믿음과의 관계를 알아본 결과, 자기성향의 학생 보다 과제성향의 학생들의 운동능력이 더 향상 되었다고 하였다. Biddle, et al(1999)도 믿음이 자기성향목표와 과제성향목표를 예측한다고 하였다. Lee \& Kim(2010)은 믿음이 숙달접근 목표성향과 수행 회피목표를 예측하다고 하였고, Park \& Kim(2010)은 운동선수의 스포츠 능력믿음과 성취목표 및 행동조절의 구조적 관계에서 학습과 노력에 의해 증가된다고 보는 믿 음은 과제성향목표를 예측하고 과제성향목표는 지각된 유능감의 매개를 통해서뿐만 아니라 직접 행동조절에 영 향을 미치는 것으로 확인 했다고 하였다.

$\operatorname{Kwak}$ (2012)은 논문에서 여자체조선수들의 성취목표 성향이 스포츠능력믿음과 체조효능감에 미치는 영향력 은 자기관리에 의해 어떻게 조절되는지를 규명하였다. 이 논문은 본 논문의 설계에서 다소 차이가 있다. 능력믿음 이 본 논문에서는 조절변수 이였으나 이 논문에서는 종속 변수로 사용하였지만 스포츠능력믿음이 성취성향에 긍 정적으로 작용한다는 것을 확인할 수 있었다.

끝으로 정신력을 본 논문에서는 자아존중감 + 의지 + 믿음으로 정의 하였다. 정신력 (자존감 + 의지 + 믿음)이 은퇴요인과 어우러져 선수생명력에 조절효과를 보이고
있는지 알아보았다. Yoo(2011)은 청소년 운동선수들의 성취와 수행을 예측할 수 있는 자기보고형 스포츠 재능발 달 척도를 개발함에 있어 12 개 요인(동적체력, 정적체력, 체격, 집중력, 조절력, 의지력, 정신적 지원, 정보적 지 원, 물질적 지원, 양적연습, 질적연습, 정신연습)과 4 개 차원(신체능력, 정신능력, 사회적 지원, 운동연습)의 위 계적 구조를 타당하게 검증 했다. 여기서 스포츠 재능의 개인적 특성은 신체능력(동적체력, 정적체력, 체격)과 정 신능력(집중력, 의지력, 조절력)의 차원으로 구분한 것은 본 연구의 정신력 안에 의지력을 포함의 이론적 배경이 될 수 있다.

현대 심리학 연구가 진행된 현재에는 정신력이라는 조 작적 정의가 어려운 개념보다는 동기이론, 회복탄력성, 심리적 강인성에 가까운 개념으로 이해되고 있다. 정신력 과 관련된 선행연구에서 Kim et al(2010)은 태권도 선수 들의 정신력 개념 구조 파악에서 정신력 개념은 집중력, 자신감, 투혼, 승부욕, 최선의 노력 등으로 정리하였다. Kim et al(2017)은 스포츠자신감의 모든 하위요인과 정 신력의 불굴의 투지간의 관계에서 과제성향은 부분매개 효과를 나타났다고 하였다. 이러한 연구는 본 연구와는 세세하게 같지는 않지만 정신력이 과제성향이나 목표지 향 성향 또는 경기력 등을 향상 시키는 요인이라는 주장 은 본 연구의 결과인 정신력이라는 조절변수는 은퇴요인 이 선수생명력에 미치는 영향에서 은퇴요인과 어우러져 유의미한 조절효과를 나타내고 있었다와 맥을 같이한다.

\section{결론 및 제언}

본 연구는 Hayes(2012)의 단순조절모형 3가지를 이 용하여 위계적조절회귀모형의 차이를 서로 비교함과 동 시에 이를 토대로 운동선수의 은퇴요인과 선수생명력간 의 관계에서 심리요인인 자존감, 의지력, 믿음의 수준에 따라 영향에 차이가 있는지 밝히고자 하는 것이 목적 이 였다. 연구 목적에 맞게 다음과 같은 두 가지 결론을 얻었다.

첫 번째 결론은 연구에 투입되는 독립변인의 수와 조 절변인의 수에 따라 결과는 크게 다르다. 어떤 모형을 선 택하느냐는 연구자의 못이지만 모형을 선택했을 때는 합 리적인 이유가 있어야한다. 투입해야 하는 변인의 당위성 
이 이론적 근거와 신뢰도가 높은 변인을 투입해야 신뢰롭 고 타당한 결과가 도출될 것이다. 모형 1 과 모형 2 에서처 럼 신뢰도가 높은 독립변수 10 개를 하나의 변수로 변환 한다면 신뢰도는 반감 될 것이고 검증력은 떨어드릴 가능 성이 높음을 알 수 있다. 모형3에서처럼 의미 있는 독립 변수는 모두 살리되 조절변수인 심리요인인 자존감, 의 지, 믿음은 인간의 정신력 안에 상호 공존하며 비례 관계 에 있음이 이론적 배경에 존재한다면 조절변인을 사용하 는 심리요인 3 가지(자존감, 의지, 믿음)를 하나의 변수 (정신력)로 변환함에 있어서는 의미가 있겠다. 따라서 구 조방정식의 연구모형과도 일치하는 모형 3 이 본 연구에서 는 합리적이며 논리적이다.

두 번째 연구결과는 은퇴요인(10가지)과 선수생명력 간의 관계에서 자존감, 의지력, 믿음에 따라 조절효과가 있는지를 검증하는 것 이였다. 3 가지 심리적요인 중에서 믿음이 은퇴요인과 어우러져 선수생명력에 미치는 영향 에서 조절효과가 가장 크게 나타났다. 조절효과가 유의미 한 것을 확인하였으므로, 조절변수의 어떤 수준에서 어떻 게 상호작용효과가 나타났는지 살펴보면 은퇴요인이 많 을수록 믿음이 강한 선수는 약한 선수보다 선수생명력은 더 오래 지속되었다. 3 가지 심리요인을 모두 합한 정신력 으로 조절효과를 살펴본 결과 은퇴요인과 어우러져 선수 생명력을 유의미하게 증가 시키는 것으로 나타났다. 특히 스포츠능력믿음이 강한 선수는 자이존중감이나 의지에 비해 은퇴요인과 잘 혼합되어 선수생명력을 더 길게 증대 시키는 결과가 초래되었다.

따라서 선수 생활을 오래하고 싶은 선수들은 대 스타 가 되는 꿈을 마음속에 항상 간직하며, 나는 선수 생활을 즐겁게 오래 할 것이라는 희망의 믿음을 항상 마음 판에 새기며 선수 생활을 할 것을 당부한다. 이를 토대로 본 연 구의 이론적 의의와 실제 상담 및 교육장에서 활용할 수 있는 시사점을 논하였고 현장에서 현역선수들에게 심리 적 요인 중 자아존중감을 키어주며, 능력믿음을 심어주는 교육을 상시 준비 할 필요성 제안한다.

\section{참고문헌}

Aguinis, H. (1995). Statistical power problems with moderated multiple regression in management research. Journal of management research, 21, 1141-1158.

Baek, H. K., \& Yang, M. H. (2016). The Effect of Leisure Motivation on Subjective Well-being: The Moderating Role of Leisure Involvement. Journal of the Korean Sports Association, 55(1), 191-205.

Baron, R. M., \& Kenny, D. A. (1986). The moderator-mediator variable distinction in social psychological research: Conceptual, strategic, and statistical considerations. Journal of Personality and social Psychology, 51, 1173-1182.

Bentler, P. M., and D. G. Bonett. (1980). Significance Tests and Goodness of Fit in the Analysis of Covariance structures, Psychological Bulletin, 88, 588-606.

Biddle, S. J. H., Wang, C. K. J., Chatzisarantis, N. L. D., \& Spray, C. M. (2003). Motivation for physical activity in young people: Entity and incremental beliefs about athletic ability. Journal of Medicine and Science in Sports, 9, 353-357.

Busemeyer, J., \& Jones, L. R. (1983). Analysis of multiplicative causal rules when the causal variables are measured the error. Psychological Bulletin, 93, 549-562.

Chae, J. S., Shin, J. J., \& Nam, D. H. (2018). Retrieval of Retirement Factors from Athletes and Validation of Measurement Tools. Korean Society for the Evaluation of Physical Education, 20(2), 67-82.

Chaplin, W. F. (1991). The next generation in moderation research in personalty Psychology. Journal of Personality, 59, 143-178.

Choi, M. S. (2018). The Causal Relationship among the Self-efficacy, Self-esteem, and School-life Adjustment of Youth Players: Focussed on the Mediating Effects of Participation-class Level. journal of the coaching ability development society, 20(4), 58-67.

Coakley, J. J. (1983). Leaving Competitive Sport : Retirement or Rebirth? Quest, 35, 1-11.

Cohen, J., Cohen, P., West, S. G., \& Aiken, L. S. (2003). Applied Multiple regression/correlation analysis for the behavior sciences (3rd ed.). Mahwah, NJ: Erlbaum.

Dweck. C. S. (1986). Motivational processes affecting learning. American psychologist, 41, 1040-1048.

Eitzen, D. S., \& Sage, G. H. (1997). Sociology of North American Sport, 5th ed. Madison, WI: Brown \& Benchmark. Empirical Considerations. Sociology of Sport Journal, 2, 101-110.

Fornell, C., \& D. F. Larcker. (1981). Evaluating Structural equation Models with unobservable variables and 
measurement error, Journal of marketing research, 18(3), 39-50.

Hair, Jr. J. F., Anderson, R. E., Tatham, R. L., \& Black, W.C. (1998). Multivariate data analysis (5th ed.). Upper Saddle River, NJ : Prentice Hall.

Hayes, A. F. (2012). PROCESS: A versatile computational tool for observed variable mediation, moderation and conditional process modeling White paper.

Heyman, G. D., \& Dweck, C. S. (1992). Achievement goals and intrinsic motivation Their relation and their role in adaptive motivation. Motivation and Emotion, 16, 231-247.

Jaccard, J., Turrisi, R., \& Wan, C. K. (1990). Interaction effects in multiple regression. Newbury Park, CA: Sage.

Jang, M. R. (2016). The Relationship between Retirement Expectation, Sense of Psychological Crisis and Re-socialization among the National Representative Athletes. journal of the korea society of social sports, 66, 229-241.

Jeon, S. W. (2014). A Study on the examination of perception reasons to the reality and drop-out of the sports major students in local universities. journal of the korea sports science society, 23(3), 73-92.

Kerr, G., \& Dacyshyn, A. (2000). The retirement experience of elite, female gymnasts. Journal of Applied Sport Psychology, $12,115-133$.

Kim, B. j. (2017). Moderating Effects of Emotional Regulation on the Relationship between Athletic Stress and Cognitive Evaluation among College Level Athletes. journal of the korea society of social sports, 67, 257-269.

Kim, C. H., \& Hong, J. S. (2015). The Study of Perception on Retirement for Professional Soccer Players. Korean Journal of Sport Science, 26(2), 320-328.

Kim, C. M., \& Kim, Y. H. (2010). The Priority Order of Psychological Decisional Factors on Taekwondo Peak Performance. The Journal of Korean Alliance of Martial Arts, 12(3), 143-157.

Kim, E. J., Jung, M. G., \& Lim, S. J. (2017). The Mediating Effects of Achievement Goal Orientation on the Relation Between Sport Confidence and Mental Power of University Taekwondo Players. The Journal of Korean Alliance of Martial Arts, 19(4), 11-28.

Kim, I. W., Shin, M. J., \& Kwon, S. H. (2014). The Impact of Perceived Coaches' Interpersonal Behaviors on the Relationship Between Self-esteem and Subjective Happiness in Young Soccer Players. journal of the coaching ability development society, 16(1), 149-156.

Kim, M. Y. (2017). Experiences of Family Resources in Resilience Development Process for Low-Income Families Participating in Asset Building Program. Family Environ. Research, 55(3), 321-336.

Kim, S. H., Roh, G. T., \& Shin, J. T. (2010). The Study of Exploring Conception of Mental toughness of Taekwondo Players through Grounded Theory Analytic Methods. The Journal of Korean Alliance of Martial Arts, 12(3), 35-47.

Kim, U. Y., \& Cho, S. j. (2016). Effects of Physical Activity Levels on Self-esteem and the Social Support in Elderly People: Moderating Effects of Gender Variable. journal of the korea society of social sports, 65, 487-496.

Kim, Y. S., Han, J. W., \& Kim, J. B. (2015). The Relationship Between Pygmalion Leadership, Organizational Commitment, Organizational Citizenship Behaviors, and Customer Orientation of Golf Club Employees: A Moderating Role of Self-Efficacy. journal of the korea society of social sports, 62, 155-171.

Kwak, S. H. (2012). The Self-Management Moderated Effect of the $2 \times 2$ Achievement Goal Orientation, Sport Ability Beliefs and Gymnastics Efficacy among Women's Gymnastics Athletics. Korean Journal of sport science, 23(2), 285-296.

Kwon, O. J., Chun, S. H., \& Song, Y. K. (2018). The Validation of the Korean Version of Mindfulness Questionnaire in the Sport Context. The Korean Journal of Physical Education, 57(4), 239-253.

Lee, J. T., \& Kim, J. W. (2009). The Relationship Between the Psychological Skills and Self Management Strategies Among Track and Field Reserve Athletes in Middle and High School. Korean Society of Physical Education, 20(4), 877-884.

Lee, K. H., \& Kim, S. J. (2010). Differences of athletic ability beliefs and basic psychological needs in physical education achievement goals profiles. Korean Journal of Sports Psychology, 21(3). 275-289.

Lee, Y. S. (2008). A Study on Retirement Preparation and Career Support for National Athlete in Korea. Korean Journal of Sport Science, 19(4), 136-145.

Lerch, S. H. (1984). The Adjustment of Retirement of Professional Baseball Players. In S. L. Greendorfer \& A. Yiannakis (Eds), Sociology of Sport : Diverse Perspectives. West Point, NY: Leisure Press, 138-148. 
McKenna, J., \& Thomas, H. (2007). Enduring injustice: A case study of retirement from professional rugby union. Sport, Education, and Society, 12, 19-35.

Oldridge, N. B. (1984). Compliance and dropout in cardiac exercise rehabilitation. journal of Cardiac Rehabilitation, 4(5), 166-177.

Park, J. G., \& Kim, K. H. (2010). Structural Relationships between Sport Ability Belief, Achievement Goal, and Behavioral Regulations among Student-Athletes: Perspective of Three Different Theories of Motivation. Korean Journal of Sports Psychology, 21(2), 103-130..

Park, C., Ji, J. G., \& Kwak, Y. S. (2018). Impacts of Exercise and Scientific Analysis on Exercise Performance of Elite Athletes. journal of the coaching ability development society, 20(1), 73-79.

Park, J. G., \& Kim, K. W. (2013). The Mediating and Moderating Effects of Emotion and Identity in the Relationships between Adolescent Athletes' Passion and Burnout. Korean Journal of Sports Psychology, 24(1), 59-79.

Park, S. G., \& Yoo, Ji. (2014). Exercise Intention and Behavior in Children: An Integrated Model for Mediation and Moderation Effects on Self-Efficacy and Parental Support. korea journal of sports psychology, 25(3), 29-44.

Park, W. H., Young, S. W., \& Cho, E. Y. (2016). The Analysis on the Career Transition of Early Retired Baseball Student-athletes by Grounded Theory. Journal of the Korean Sports Association, 55(1), 509 520.

Sarrazin, P., Biddle, S., Famose, J. P., Cury, F., Fox, K., \& Durand, M. (1996). Goal orientations and conceptions of the nature of sport ability in children: A social cognitive approach. British Journal of social psychology, 35, 399-414.

Seo, Y. S. (2010). Testing Mediator and Moderator Effects in Counseling Psychology Research: Conceptual Distinction and Statistical Considerations. The Korean Journal of Counseling Psychotherapy. 22(4), 1147-1168.

Shin, S. M., \& Kang, I. P. (2014). Influential Psychological Factors for Athletic Performance in Poomsae Competition. The Journal of Korean Alliance of Martial Arts, 16(1), 71-83.

Tak, J. k., Lee, E., \& Lim, G. J I. (2013). Development and validation of the Career Concern Inventory. Korean Journal of Sports Psychology, 26(1), 27-46.

Won, Y. I., \& Kim, J. T. (2017). Development and Validation of the Retirement Anxiety Questionnaire for College Athletes. Journal of the Korean Sports Association, 56(6), 351-362.

Won, Y. I., Kim, J. T., \& Kim, H. H. (2018). Relationship among Self-efficacy, Stress Coping Style, and Retirement Anxiety of University Taekwondo Players. Journal of the Korean Sports Association, 57(2),225-238.

Yoo, J. (2011). Development of the Multidimensional Talent Development Scale: Hierarchical and Invariance Analyses. Korean Journal of Sports Psychology, 22(1), 111-128.

Yoon, J. W., Moon, Y., \& Joo, S. T. (2011). The Study on Mediated Effects of Self-esteem and Moderated Effects of Self-efficacy Between Sports Voucher Participation and Self-leadership of Low-income Family Adolescents. Journal of the Korean Sports Association, 50(6), 75-89. 


\title{
운동선수의 은퇴요인과 선수생명력의 관계에서 심리요인의 조절효과 모형비교
}

\author{
채진석 \\ 서울과학기술대학교 초빙조교수
}

〔목적〕 본 연구는 Hayes(2012)의 단순조절모형 3가지를 이용하여 위계적조절회귀모형의 차이를 서로 비 교함과 동시에 이를 토대로 운동선수의 은퇴요인과 선수생명력간의 관계에서 심리요인인 자존감, 의지력, 믿 음의 수준에 따라 조절효과가 있었는지 밝히고자 하는 것이 목적이다. 〔방법) 이러한 목적을 달성하고자 총 259 명의 은퇴자를 대상으로 은퇴요인, 심리요인 자료를 수집하였다. 자료처리방법은 기술통계, 빈도분석, 확 인적요인분석, 신뢰도분석으로 측정도구의 신뢰도와 타당도를 제시하였다. 또한 IBM 20에서의 PROCESS 명령문을 이용하여 위계적회귀분석를 실시하여 조절효과를 살펴보았다. 〔결과〕 연구결과는 다음과 같다. 첫 번째는 Hayes (2012)의 단순조절모형 3가지 중 모형3이 유의미한 모형 이였다. 어떤 모형을 선택하느냐는 연구자의 몫이지만 모형을 선택했을 때는 변인의 당위성이 이론적 근거에 의해 성립되어야하며, 아울러 신뢰 도가 높은 변인을 투입해야 신뢰롭고 타당한 결과가 도출될 것이다. 두 번째는 은퇴요인(10가지)과 선수생명 력 간의 관계에서 자존감, 의지력, 믿음에 따라 조절효과가 있는지를 검증하는 것 이였다. 심리적요인 중에서 믿음이 은퇴요인과 어우러져 선수생명력에 미치는 영향에서 조절효과가 가장 크게 나타났고 은퇴요인이 많을 수록 믿음이 강한 선수는 약한 선수보다 선수생명력은 더 오래 지속되었다. 3 가지 심리요인을 모두 합한 정신 력으로 조절효과를 살펴본 결과 또한 은퇴요인과 어우러져 선수생명력을 유의미하게 증가 시키는 것으로 나타 났다. 특히 스포츠능력믿음이 강한 선수는 자이존중감이나 의지에 비해 은퇴요인과 잘 혼합되어 선수생명력을 더 길게 증대 시키는 결과가 초래되었다. (결론) 따라서 선수 생활을 오래하고 싶은 선수들은 대 스타가 되는 꿈을 마음속에 항상 간직하며, 나는 선수 생활을 즐겁게 오래 할 것이라는 희망의 믿음을 항상 마음 판에 새기 고 선수 생활을 할 것을 당부한다.

주요어: 은퇴요인, 심리요인, 선수생명력, 조절효과 